\title{
SUSTAINABLE RESOURCE MANAGEMENT BY STUDENTS AT HIGHER EDUCATION INSTITUTIONS
}

\section{Ian Williams * and Lorna Powell}

University of Southampton, Faculty of Engineering and Physical Sciences, Southampton, United Kingdom

Article Info:
Received:
19 July 2018
Revised:
21 November 2018
Accepted:
17 January 2019
Available online:
23 April 2019
Keywords:
Circular Economy
Reuse
Higher education institutions
Key performance indicator
Waste management
Sustainability

\section{INTRODUCTION}

"Shift Your Stuff" is an annual scheme run by the Southampton University Students' Union (SUSU). The scheme involves distributing collection bags to students at the end of the summer term, and providing a service to collect or drop-off donations of unwanted items. The SUSU then redistributes them for reuse or resale by charities. As well as charitable benefits to the community, the scheme works to alleviate complaints by residents of the city of Southampton about the mess left by students in streets when they move out of accommodation at the end of the academic year. It also retains materials and resources in the circular economy, reducing pressure on resources and promoting reuse and recycling to the student community.
During 2015/16, a protocol was developed to set out a recommended timescale of what should be done to execute the project, and when each task should be completed ( $\mathrm{Pa}$ tel, 2016).

\subsection{Consumerism and resource consumption}

Current consumerism is driving pressure on resources across the globe; 'fast fashion' is reinforcing the 'take, make, dispose' linear economy, in which resources are used few times before being sent for final disposal. For example, so-called "fast fashion" is a system that produces fashionable items in short times in order to respond to rapidly changing consumer demands (Diop and Shaw, 2018; Cachon and Swinney, 2011). The global retail textile industry reached a value of over \$1.2 trillion in 2014 and, 
as one of the world's principal industries, this sector impacts significantly upon the environment (Diop and Shaw, 2018; Resta \& Dotti, 2015) It is a highly turbulent industry - with trends changing regularly and 'fashion seasons' being short (Bruce and Daly, 2006) and with shops bringing in new garments in every few weeks (Joy et al., 2012), the perfect conditions are created to encourage customers to shop regularly and accumulate goods quickly. Some products may only have a 'fashionable' life cycle of weeks (Sull and Turconi, 2008) resulting in many items (between one third to a half of all items sold (Bruce and Daly, 2006) having to be sold at mark-down prices. This is making low quality garments even more accessible, driving consumers away from high quality, longer-lived products.

There is a growing recognition that resources must be conserved and an increasing understanding of the need for circular economy behaviour in order to protect resources and the environment. For example, Diop and Shaw (2018) highlighted that it is crucial citizens view end-of-use clothing and textiles in terms of their value as a resource in adherence to the aims and principles of the waste hierarchy. Indeed, consumers are starting to resist consumerism - people are becoming more aware of the impact of their purchases and are making conscious decisions to move away from consumption and its environmental impacts (Joy et al., 2012; Kozinets and Handelman, 2004). In some developed countries, reuse, refurbishment and repair of "pre-loved" or "pre-owned" items is increasingly becoming a lifestyle choice for many people (Williams and Shaw, 2017). However, the cost of ethically produced, long-life products may not be a priority for all, especially students who may prioritise spending on other items or activities. People with environmental values may utilise other methods of reducing their environmental impact through the responsible disposal of their unwanted goods (Joung and Park-Poaps, 2013). This environmental consciousness, and understanding of the impacts of production and consumption, is driving an increase in public participation in 'reuse' schemes in communities around the world (Bianchi and Birtwistle, 2010).

Young people are the most concerned with buying 'trendy', cheap clothing (Morgan and Birtwistle, 2009). Within this group the demand for cheap clothing is high, and the availability and access to these goods means that it is increasingly easy to buy and accumulate large amounts of cheap, low quality goods. Add to this the stash of free promotional t-shirts a student will receive during their time at university, and you have students with wardrobes stocked with garments they feel little attachment to. It has been found that consumers feel a low sense of attachment to cheap items, and do not feel guilty about disposing of them (Birtwistle and Moore, 2007). This mind-set is especially present in student communities (Students and Staff of the Centre for Environmental Science, 2017). Due to the nature of their living situation, many students tend to purchase cheap items which only need to serve a purpose over a couple of years. At the point of purchase these items are often destined to be thrown away within three years, if they haven't already broken. So, at the end of the academic year large volumes of reusable goods are disposed of by students who are leaving university. Birtwistle and Moore (2007) found that consumers were more likely to donate these unwanted items to charity, if prompted to do so. Shift Your Stuff was designed to appeal to the student population and encourage responsible disposal by providing a prompt to encourage students to donate their unwanted items, instead of disposing of them. If students have accumulated large amounts of cheap clothing that they do not feel attached to, they are likely to dispose of it when they move out of their house rather than moving it with them. Shift Your Stuff can intervene and divert these goods from landfill redirecting them towards reuse or recycling. completed (Patel, 2016).

\subsection{Waste issues and reuse schemes}

At the end of the summer term in university towns in the United Kingdom (UK), tens of thousands of students will move out of their rented homes and in the process, generate large quantities of waste (Zhang et al, 2011). It is hard to miss the waste issues that are generated by the student move-out period. It is publicised in local newspapers and often through local news and radio - overflowing bins are in abundance, which can in turn generate issues with vermin, odours, and health and safety (Bristol Post, 2016, Waddington, 2016). These issues are put down to student clear outs and can cause tension between permanent residents and transient student populations (Keep Britain Tidy, 2013). Many residents claim that students have a disregard for their area because they may only be there for a year or two, and feel little pride in keeping the area looking nice. But students may justify their actions by claiming that waste disposal options are limited. Bin size restrictions can cause issues for houses of multiple occupancy (HMOs) with only one wheeled bin serving up to seven or so residents, a particular issue during periods of high waste generation such as during the move-out period (Williams and Cole, 2013; Gosling, 2016). Access to civic amenity (CA) sites may also be limited for many students due to the restricted transport options of a typical student, meaning that they may find it impractical to dispose of their waste elsewhere, especially if they have large quantities that cannot be carried on public transport (Williams and Taylor, 2004). These combined factors cumulate in streets containing overflowing bins and extra bags of waste on streets, conditions that can attract both vermin and scavengers, often resulting in waste being scattered across the streets of student dominated areas.

Waste management schemes in higher education institutions (HEIs) can play an important role in alleviating the problems associated with the student move out (Zhang et al, 2011). Reuse schemes such as Shift Your Stuff can divert student waste from disposal, creating space in bins and alleviating pressure on waste collection authorities and councils that have to handle the responsibility of clearing up the waste. The positive impact of end-of-term reuse schemes has been seen in Bristol, where litter complaints fell by $28 \%$ once the 'Bristol Big Give' reuse scheme began in the city (Bristol Post, 2016).

A review of reuse schemes has found that a kerbside collection can come with associated problems, with a possible issue being scavenging. Between the point when 
bags are left out for collection by students and them being collected by the team working for the scheme, scavengers may tear open bags in search of items which may be beneficial to them. This action can cause health and safety problems, as well as being an unsightly nuisance to the community.

Charity reuse schemes can aid many issues: litter problems can be alleviated; resources conserved; social benefits generated; and deprived members of the community helped (Horne, 2000). These schemes are becoming increasingly common in HEls. The British Heart Foundation 'Pack for Good' campaign currently has 80 partnering universities and has raised over $£ 1.5$ million through 2,200 tonnes of donations since the scheme launched in 2011 (BHF, 2016b).

\subsection{Key performance indicators}

Key performance indicators (KPIs) are a way to measure performance in a repeatable way which will produce results which can be reliably compared (Williams and Shaw, 2018). They are a straightforward way of measuring results and presenting results in both technical and non-technical ways (Del Borghi et al., 2009). Typical KPIs for waste management include strategies include weight diverted from landfill (WRAP, 2016) and carbon footprinting (ICAEW, 2017). Shift Your Stuff uses KPIs to measure the success of the scheme. These have been developed to produce consistent datasets year on year, making the results easily and reliably comparable. They are also an effective way to relay the success of the scheme to the public (Del Borghi et al., 2009) without having to give complicated figures. KPIs were developed for the 2015/16 Shift Your Stuff; variations on traditional waste management KPIs had to be created to be appropriate for a reuse scheme (Table 1). This paper considers the effectiveness of KPI use for quantifying the success of a reuse scheme.

\section{METHODS}

\subsection{Desk study}

A thorough review of reuse schemes at UK HEls (Appendix 1) was conducted to gain an understanding of the characteristics of some of the most successful schemes and to see how they may be applied to Shift Your Stuff. Summaries of these findings can be seen in Appendix 2.

TABLE 1: Key performance indicators (KPIs) for Shift Your Stuff.

\begin{tabular}{ll} 
Key Performance Indicator & Description \\
\hline Summary & $\begin{array}{l}\text { Measures the percentage of all the collect- } \\
\text { ed donations that is sent for reuse. } \\
\text { The weight of each material category } \\
\text { which is reintroduced to the circular econ- } \\
\text { omy through the scheme. } \\
\text { Onvironmental } \\
\text { The amount of money raised for chari- } \\
\text { ty from the resale of the items donated } \\
\text { through the scheme } \\
\text { A qualitative summary of the social ben- } \\
\text { efits that are brought about by the dona- } \\
\text { tions, or the money raised by the resale of } \\
\text { the donations. }\end{array}$ \\
\hline
\end{tabular}

A SWOT (strengths, weaknesses, opportunities and threats) analysis from Patel (2016) was used as a framework and, from the report and undertaking discussions with people who have been previously involved with the scheme, additional strengths, weaknesses, opportunities and threats were identified. The SWOT analysis was amended accordingly (Table 2 ).

\subsection{Protocol development}

Analysis of the existing Shift Your Stuff protocol (Patel, 2016; available on request via idw@soton.ac.uk) was undertaken by discussing the tasks and timescales with the Shift Your Stuff team. Each task on the protocol was assessed for necessity, appropriateness of the timings and suitability of the person assigned to carry it out. If tasks were deemed to need additions and/or alterations to timings then the suitable changes were agreed on by the Shift Your Stuff team and noted on the protocol.

As outlined in Section 1.3, there has been some focus on developing methods for measuring the impact of reuse (Castellani et al., 2015; WRAP, 2011), although it has been recognised that there are complexities when doing this (Fortuna \& Diyamandogly, 2016; Alexander and Smaje, 2008). Whilst KPIs for recycling are well-established and widely used, data collection for reuse is challenging. There is a clear need for reuse-related KPIs so that the impacts of reuse can be measured, monitored and demonstrated over time. In this context, the key performance indicators developed by Patel (2016) were reviewed and where it was found that there were problems with the KPI data collection in the previous year, appropriate changes were made.

\subsection{Collection, sorting and processing of donations}

Donations could be made in two different ways. These were promoted via posters and blogs written by officers of the Southampton University Students' Union (see examples at: https://blogs.susu.org/officers/2016/05/24/shift-yourstuff-2016/ or https://blogs.susu.org/blog/2017/05/15/ shift-your-stuff-2017-a-spring-clean-is-the-dream/).

The scheme offered drop-off points at University of Southampton campuses where students could deposit their donations in branded donation bins. These points were available for deposits from the end of May to the end of June. The second method which could be utilised to make a donation was kerbside collection. Kerbside collections took place on specific days in June 2017. Students were advised to leave donations in branded red bags outside their property on the morning of each collection. Employees from the city council then collected any red bags from kerbside in the student areas of the city delivered them to the sorting rooms at an identified campus (Highfield). Details on how to donate were printed on leaflets and handed out at University of Southampton campuses.

Volunteers were recruited to assist with sorting and processing the donations. Recruitment was undertaken via posters, word-of-mouth, social media, and by email to selected groups of student (e.g. students studying Environmental Science; see Appendix 3). Each bag of donations was opened and visually checked to ensure the contents were of one category; in cases where categories were 
TABLE 2: SWOT analysis of the 2015/16 Shift Your Stuff. Original evaluation carried out immediately after the previous year's project is in shaded boxes, additional strengths, weaknesses, opportunities and threats identified prior to this year's project are unshaded.

\begin{tabular}{|c|c|}
\hline Strengths & Weakness \\
\hline $\begin{array}{l}\text { Having items pre-sorted into categories reduced sorting } \\
\text { time required }\end{array}$ & $\begin{array}{l}\text { Inconsistent data (can't compare years), digital scales were lost before the second round of } \\
\text { sorting. }\end{array}$ \\
\hline $\begin{array}{l}\text { The quality of the items was increased (less waste pro- } \\
\text { duced than the previous year), potentially because of the } \\
\text { categories. }\end{array}$ & $\begin{array}{l}\text { Some bags picked up by Southampton City Council from the streets didn't have stickers on and } \\
\text { contained a mixture of categories. }\end{array}$ \\
\hline $\begin{array}{l}\text { The charities agreed in advance what they would take, } \\
\text { and came to collect it. }\end{array}$ & The quality of sorting was dependent on the quantity of bags that needed sorting at the time. \\
\hline $\begin{array}{l}\text { Less storage space was needed as the charities collect- } \\
\text { ed soon after items had been sorted. }\end{array}$ & If there were a lot of bags, the sorting became less thorough. \\
\hline $\begin{array}{l}\text { By taking photographs, data could be collected and } \\
\text { stored in a quick way. }\end{array}$ & $\begin{array}{l}\text { The marketing team put a picture of an electrical item on the category stickers meaning a lot } \\
\text { of electricals were donated even though Union Southampton had asked for students not to } \\
\text { donate these. }\end{array}$ \\
\hline $\begin{array}{l}\text { Data collection more consistent across the sorting days } \\
\text { than the previous year (though still some issues). }\end{array}$ & $\begin{array}{l}\text { The kitchen utensils category was quite fragile so the items would easily break if not handled } \\
\text { correctly. }\end{array}$ \\
\hline \multirow[t]{2}{*}{ Baseline data started to be collected from the KPIs } & $\begin{array}{l}\text { A technological issue for storage of the photographs resulting in the photographs from the first } \\
\text { round of sorting being lost. }\end{array}$ \\
\hline & Total weight was lower than the previous year. \\
\hline $\begin{array}{l}\text { Student's unwanted items were diverted from final dis- } \\
\text { posal for reuse. }\end{array}$ & Limited data- only the number of bags and their weight. \\
\hline Waste issues on the streets were reduced. & Inadequate staffing/volunteering. \\
\hline $\begin{array}{l}\text { Many students dropped items off at drop off points, or } \\
\text { left them for kerbside collection. }\end{array}$ & Relatively low participation in comparison to student population. \\
\hline The scheme was supported by SCC and the BHF. & Low number of donations to the first collection, possibly arranged too early. \\
\hline \multirow[t]{2}{*}{$\begin{array}{l}\text { The scheme set a good example for resource manage- } \\
\text { ment in the city }\end{array}$} & $\begin{array}{l}\text { Some charities were unhappy with donation quality/sorting, Communications with charities } \\
\text { could have been better to have a good idea of what they wanted and what was required of them. }\end{array}$ \\
\hline & No data on the demographics of the participants. \\
\hline Opportunities & Threats \\
\hline $\begin{array}{l}\text { Unsure of the number of students who took part in the } \\
\text { project }\end{array}$ & $\begin{array}{l}\text { Not all of the charities were happy with the items donated, for example, some items were not } \\
\text { appropriate for the function of their charity. }\end{array}$ \\
\hline $\begin{array}{l}\text { There was some overlap with the categories and some } \\
\text { confusion of what items should go into which category }\end{array}$ & Some issue with the number and reliability of volunteers \\
\hline $\begin{array}{l}\text { Results don't include halls of residence donations (as } \\
\text { some other universities do); inclusion of this could im- } \\
\text { prove results. }\end{array}$ & $\begin{array}{l}\text { Poor marketing of the scheme- if participation is too low, the scheme may not be worthwhile } \\
\text { running }\end{array}$ \\
\hline
\end{tabular}

co-mingled the items would be separated out into single category bags (Figure 1). At this stage, items that were not suitable for donation were separated and moved to a designated area; such items included electricals, sharps and waste. The next stage was to weigh each bag of donations (using Tefal mechanical scales). Each value was logged in kg on pre-prepared data sheets. Finally, each bag was re-opened and a digital photograph was taken of the contents. The bags were laid out in segregated categories (Figure 2), so that the charities would be able to easily take whichever categories they had agreed to take when they collected, meaning the process would run as smoothly as possible.

The purpose of inspecting the donations is to remove items that are unsuitable for donation to charity. Such items may include dirty, dangerous or broken items, or open items of food. The total weight of all unsuitable items was recorded on a spreadsheet in $\mathrm{kg}$.

The contents of each bag of donations were also photographed in order to analyse the material composition to minimise the time required for data collection on the sort- ing days. Photographs were grouped and analysed one category at a time. In each photograph, the materials present were identified and percentage dominance of each material was estimated. The estimated weight of each material returned to the circular economy was calculated using the composition and the category weight (Table 5, Table 6).

Participants were provided with category stickers so that bags could be easily identified according to what was inside. Each sticker had space to fill in details on student type (UG, PGR, PGT), and nationality (UK, EU, international) and number of bags donated. This was provided in order to be able to collect demographic data on the participants of the scheme. In the cases where these details had been filled in, the responses were recorded on the pre-prepared data sheets.

By email, charities were provided with a simple questionnaire to fill out after the donations had been made to them. This questionnaire asked questions which would generate results for the social and economic KPIs, such as how much money they expected to raise from donations and what social benefits they can generate with that mon- 


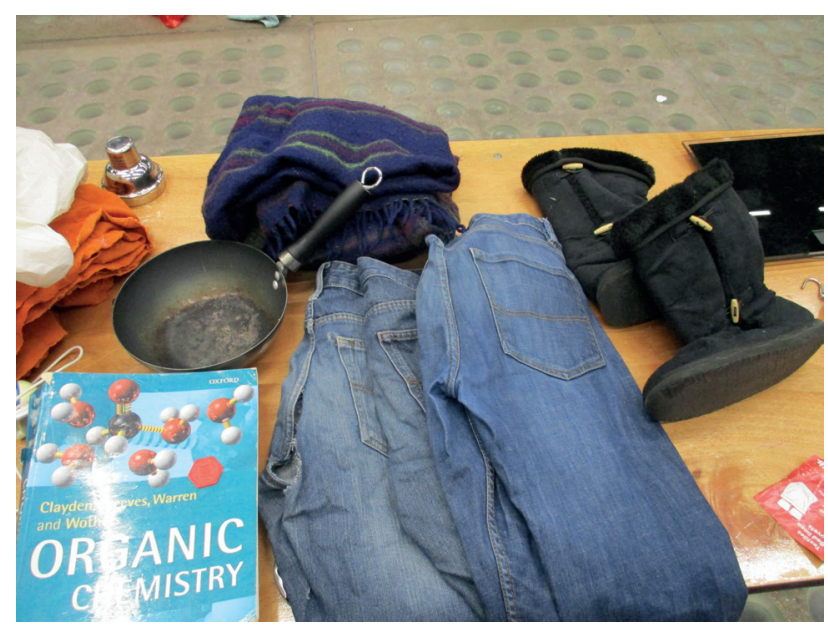

FIGURE 1: Example of a bag that contained co-mingled materials.

ey (Table 7). After data collection was complete, a SWOT analysis was undertaken to identify the new strengths, weaknesses, opportunities and threats to Shift Your Stuff (Table 8).

As the bags of donations were collected by each charity, the numbers of bags from each category taken were tallied on a spreadsheet so that accurate donation figures would be known during follow up communication regarding social and economic benefits. Shift Your Stuff donated goods to various charities - the main beneficiary was the British Heart Foundation. Other charities that took donations were Southampton Refugee Action, Patrick House, St Francis Animal Welfare, Dogs Trust and Jamie's Computers. Most charities pre-arranged a collection time and date, and informed SUSU what they would like to take. Donations for Jamie's Computers and the Dogs Trust were delivered to their local sites.

During the sorting process, an unexpected, opportunistic partnership was formed with the student marketplace 'Stradents'. The director of the scheme came along to the second sorting day and an agreement was made that much of the kitchenware would be made available for a charity sale for pre-sessional, international students new to the university (Figure 3). The items were stored in a room in a SUSU building for two days until the sale took place. Kitchenware items were laid out by category and a donation bucket was provided. Students were encouraged to make a small charity donation in exchange for any kitchenware they wanted from the selection. The sale was advertised on the Stradents social media pages, and the university 'Me-chat' service, a messaging platform for pre-sessional students.

\section{RESULTS}

\subsection{SWOT analysis}

The results of the SWOT analysis are shown in Table 2.

\subsection{Project development}

The review of the existing protocol resulted in a number of alterations being made (Table 3 ); the revised proto-

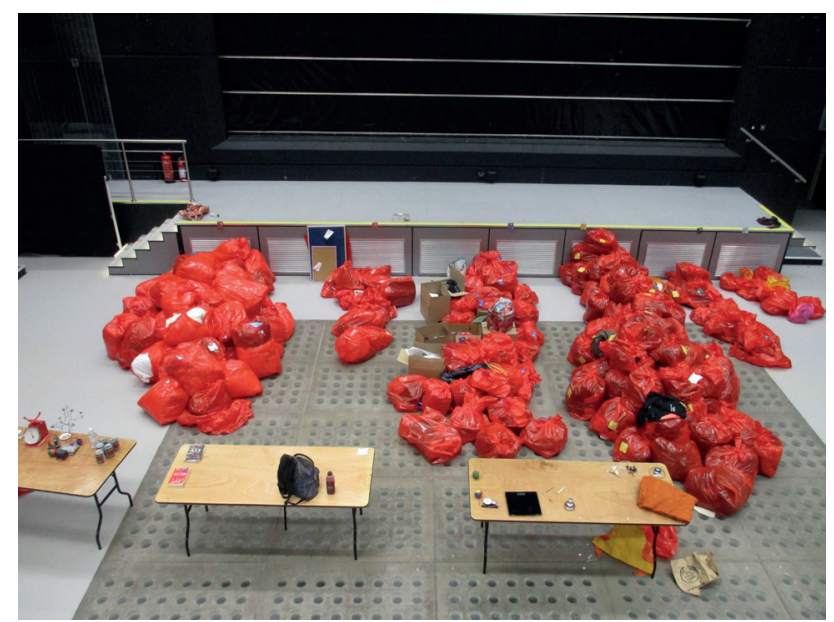

FIGURE 2: Categorising sorted bags ready for collection

col can be obtained upon request (to idw@soton.ac.uk). Changes to marketing timescales were made in order to maximise the time over which students were exposed to marketing for the scheme through social media and campus advertising. This is important because if advertising is launched after students finish lectures and exams, as the previous protocol advised, many may not be on campus regularly and therefore not see the advertising. Access to to the scheme was planned to be extended by launching the drop-off period earlier in the term. Many students com-

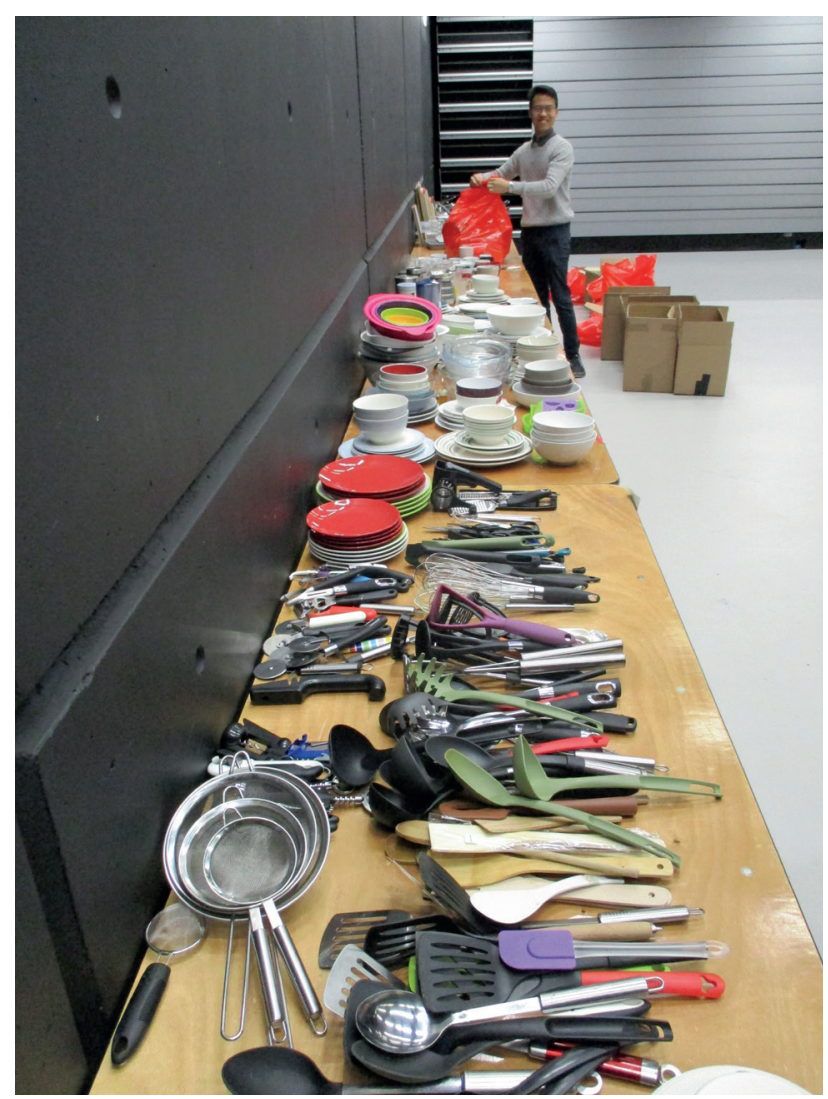

FIGURE 3: Set up for the pre-sessional kitchenware sale. 
plete 'coursework only' modules in their final year, meaning that they finish university around mid-May. If the drop-off period is to start after this point an opportunity may be missed to gain donations from those leaving, final year students - the main target audience of the scheme. As the system for donations only requires for drop-off bins to be provided on campus, it is of no inconvenience to move this forward in the term, as long as the space is available.

After analysis of the KPIs, changes were suggested in order to improve the reliability of the data collection for the KPIs. Suggestions included collecting more detailed data, but it was agreed that the possible improvements were not realistically attainable - time and (wo)man-power limitations on the sorting day mean that data collection must be limited to methods that are fast and simple to conduct, making a more detailed analysis impractical. Because of this the indicators remained the same. This exercise did, however, draw attention to areas where it was most important to use consistent methods to collect full and reliable data sets. It also highlighted a need for more data on who is participating in the scheme and how much they are contributing. To collect this data the category stickers provided to participants to label their donation bags were designed to include space for the participants to fill in demographic data (type of student and nationality), as well as the number of bags they had donated. This was hoped to provide new data on which student groups are participating in the scheme, and which groups should be targeted with marketing in the future.

The analysis of last year's project revealed that there was confusion between the charities and SUSU regarding what type of item each charity could take, in what quantities and when they would like to collect. This problem was designed out through amendments to the protocol. Communication with charities before the event meant it was agreed in advance how much the smaller charities would like to receive, the BHF confirmed that they could take whatever else remained, and ensuring there would be minimal items that couldn't be taken by any charities.

A weakness identified from the 2015/16 Shift Your Stuff data collection was that the loss of weighing equipment, along with technological issues with a camera resulting in loss of photographic data, meant that weight and pho- tographic datasets were incomplete and inconsistent. To avoid this happening again, it was ensured that all pieces of equipment (such as scales and cameras) had multiple back-ups, so that should one fail, data collection could continue. Volunteers were thoroughly briefed on the procedure to follow for the processing of the donations, to ensure that data collection was consistent.

\subsection{Summary KPIs}

\subsubsection{Summary KPI: The percentage of all items collected that was sent for reuse}

This KPI is designed to give a quick and simple way to measure and compare the success of the project year-onyear. The data used to generate a figure for this KPI was collected during the sorting process: the total weight of the incoming donations; and the total weight of items which could not be sent for reuse (waste). From these the total percentage reuse was estimated via Equation 1. Percentage reuse indicates the amount diverted from final disposal out of all the donations made. This figure can be compared to that of previous years to assess the success of the scheme, and the quality of donations being received.

During this year's project, a total of $2252.9 \mathrm{~kg}$ was donated, of which $170.7 \mathrm{~kg}$ had to be sent for final disposal due to being unsuitable for reuse. Using these figures, a total $92.4 \%$ reuse rate from this year's project was calculated. Last year the reuse rate came to $90.9 \%$, meaning that in 2016/17 a slight increase in reuse rate has been achieved (Table 4). This suggests that students have provided a higher quality of donation to the scheme.

Equation 1: Calculation for Summary KPI: Percentage reuse Percentage reuse $(\%)=\frac{100^{*} \text { Total incoming donations }(\mathrm{kg}) \text { - total waste }(\mathrm{kg})}{\text { Total }}$

\subsubsection{Environmental KPI: The weight of each material put} back into the circular economy through the scheme

The action of taking a photo of the contents of each bag takes very little time but provides a valuable source of data that can be analysed after the donation sorting has been completed. This KPI was developed as an alternative to carbon footprinting, which can be very time and data

TABLE 3: Problems identified during the review of the protocol, and the changes which were made to avoid, reduce or minimise these problems in the future.

\begin{tabular}{|c|c|}
\hline Problem & Alteration \\
\hline $\begin{array}{l}\text { Many tasks were assigned to the 'Shift Your Stuff assistant', } \\
\text { a role that no longer exists. }\end{array}$ & $\begin{array}{l}\text { Task responsibilities had to be reassigned to various team members within the team running } \\
\text { the scheme. }\end{array}$ \\
\hline $\begin{array}{l}\text { There was no opportunity to allocate tasks to team mem- } \\
\text { bers. }\end{array}$ & $\begin{array}{l}\text { A task was introduced which instructed the allocation of responsibilities to appropriate to } \\
\text { team members. }\end{array}$ \\
\hline $\begin{array}{l}\text { The marketing launch date was deemed to be too late in the } \\
\text { term- after the university summer exam period was over. }\end{array}$ & $\begin{array}{l}\text { There was a general agreement that marketing should be launched when students return } \\
\text { from the Easter break (week } 30 \text { ) to maximise exposure. }\end{array}$ \\
\hline The drop off period for donations began too late in the term. & The drop off period was suggested to be extended earlier in the term. \\
\hline Problems recruiting volunteers and increasing participation & $\begin{array}{l}\text { It was suggested that the Shift Your Stuff team contacts charity groups within the university, } \\
\text { such as Raise and Give (RAG), to see if any would be willing to participate in the running of } \\
\text { the scheme. This would bring extra publicity, and extra volunteers, to the scheme }\end{array}$ \\
\hline $\begin{array}{l}\text { Charities were contacted too few times, and late on in the } \\
\text { process, to discuss what donations they would like, and } \\
\text { what volume they could take, resulting in confusion be- } \\
\text { tween charities and SUSU. }\end{array}$ & $\begin{array}{l}\text { It was agreed that regular contact should be kept between SUSU and each charity, via email, } \\
\text { to ensure both parties knew what their expectations were of what we would provide them, } \\
\text { how much they could take, and to organise collection times. }\end{array}$ \\
\hline
\end{tabular}


TABLE 4: Summary KPI: Percent reuse for the 2015/16 and 2016/17 Shift Your Stuff.

\begin{tabular}{c|cccc} 
& $\begin{array}{c}\text { Sorting } \\
\text { Round 1 }\end{array}$ & $\begin{array}{c}\text { Sorting } \\
\text { Round 2 }\end{array}$ & $\begin{array}{c}\text { Overall percent } \\
\text { reuse }\end{array}$ \\
\hline $\begin{array}{c}\text { Percent reuse } \\
2015 / 16(\%)\end{array}$ & 94.63 & 81.41 & 90.88 \\
\hline $\begin{array}{c}\text { Percent reuse } \\
2016 / 17(\%)\end{array}$ & 93.25 & 92.24 & 92.42 \\
\hline
\end{tabular}

intensive, making it impractical for this scheme. A breakdown of the materials returned to the circular economy from each category is shown in Table 5 as well as totals for each material (Table 6).

\subsubsection{Economic KPI: A measure of the amount of money raised through the scheme.}

This KPI was calculated by summing the total values of all donations collected through the scheme. As donations were split between 6 charities as well as pre-sessional students it is a challenge to agree upon a single, consistent value for each bag of donations. Each bag of donations varied in weight, quality and content- the bag weight ranged from $0.3-20 \mathrm{~kg}$ meaning that values varied greatly between bags. Due to the varying value of donations between charities it is important to speak to each charity to find out the value of the donations they were provided to them. So, after donations were passed over to the charities, follow up emails were sent to assess what value they typically place on each bag of donations they receive, these values vary between charities as they may sell items for different prices in their stores, or the perceived value may vary when the items are being directly used by the beneficiaries. The bag values and number of bags donated were then used to calculate an estimate of the amount of money each charity would generate from Shift Your Stuff. The British Heart Foundation were the only charity to respond to the economic KPI email, they stated that they place an average value of $£ 10$ on a bag of donations received from the University of Southampton, meaning that the total value of the donations made to the BHF through Shift Your Stuff was $£ 1,690$. The remaining donations were spilt between 5 other charities, from which responses were not received. These donations made up $49 \%$ of everything distributed to the charities, if these charities place a similar value of $£ 10$ on each bag of donations received, then the extrapolated value of all donations comes to $£ 3,362$. Additionally, the Stradents pre-sessional sale raised a total of $£ 112$ which went straight to the RAG charities, meaning that in total Shift Your Stuff raised $£ 3,474$ for a variety of good causes.

\subsubsection{Social KPI: A qualitative summary of the social bene- fits brought about by the scheme.}

Following the donation of goods to the charities, emails were sent to find out what social benefits are brought about by the charities as a direct result of the donations. During the 2015/16 project, the response rate from charities was low, so in 2016/17 it was advised that the team running the scheme kept regular contact with the charities to make sure it was clear all parties expected from the scheme. Instead of a formal questionnaire, which may be daunting to a busy charity, this year a simple e-mail was sent out asking about the social benefits brought about by the scheme. Again, the response rate from the charities was low with only the British Heart Foundation responding. Hence, it was necessary to consult the websites of the rest of the charities to gain a summary of the social benefits they create through their work (Table 7).

\subsection{Pre-sessional sale}

The Stradents pre-sessional sale provided a platform to sell donated kitchenware to pre-sessional students who had just arrived in Southampton. This initiative

TABLE 5: Environmental KPI: weight of each material returned to the circular economy. This was worked out using material dominance (from photographs) in each category and total category weights.

\begin{tabular}{|c|c|c|c|c|}
\hline Category & Weight (kg) & Materials & $\%$ composition & Estimate of weight into CE (kg) \\
\hline Clothing and Footwear & 706.25 & $\begin{array}{l}\text { Textiles } \\
\text { Leather } \\
\text { Rubber } \\
\text { Plastic }\end{array}$ & $\begin{array}{c}89 \\
4 \\
4 \\
2\end{array}$ & $\begin{array}{c}628.6 \\
28 \\
28 \\
14\end{array}$ \\
\hline Bedding and Linen & 305.45 & Textiles & 100 & 305.4 \\
\hline Kitchen and homeware & 722.20 & $\begin{array}{c}\text { Textiles } \\
\text { Plastic } \\
\text { Ceramic } \\
\text { Metal } \\
\text { Glass } \\
\text { Wax } \\
\text { Wood } \\
\text { Paper/Card }\end{array}$ & $\begin{array}{c}7 \\
23 \\
12 \\
33 \\
6 \\
1 \\
11 \\
9\end{array}$ & $\begin{array}{c}50.6 \\
166 \\
87 \\
33 \\
43 \\
7 \\
79 \\
65\end{array}$ \\
\hline Food & 102.95 & $\begin{array}{c}\text { Plastic } \\
\text { Metal } \\
\text { Glass } \\
\text { Paper/Card }\end{array}$ & $\begin{array}{c}12 \\
70 \\
10 \\
8\end{array}$ & $\begin{array}{l}12 \\
72 \\
10 \\
8.2\end{array}$ \\
\hline Books games disks & 230.4 & $\begin{array}{c}\text { Plastic } \\
\text { Metal } \\
\text { Paper/Card }\end{array}$ & $\begin{array}{c}13 \\
3 \\
84\end{array}$ & $\begin{array}{c}30 \\
7 \\
193.5\end{array}$ \\
\hline
\end{tabular}


TABLE 6: Total values for the environmental KPI: the total weight of each material returned to the circular economy through the scheme.

\begin{tabular}{|c|c|}
\hline Material & Weight back into CE (kg) \\
\hline Textiles & 984.6 \\
\hline Leather & 28 \\
\hline Rubber & 28 \\
\hline Plastic & 222 \\
\hline Ceramic & 87 \\
\hline Metal & 106 \\
\hline Glass & 53 \\
\hline Wax & 7 \\
\hline Wood & 79 \\
\hline Paper/card & 266.7 \\
\hline
\end{tabular}

meant that the kitchenware required minimal transportation, and that it was incorporated straight back into the circular economy, rather that possibly being sat in storage before being sold in a charity shop. Another benefit of this system was that it was directly helping new students at the university and spreading awareness of the scheme. As these beneficiaries are only at the university for one year, it is hoped that when they are finished with the items they will be donated back to the scheme during next year's run. This sale raised $£ 112$ and was attended by over 100 students.

\subsection{Student demographics}

Of the 548 bags that were donated to the scheme, only 35 people completed the demographics sticker provided, meaning that solid conclusions cannot be made about the types of students participating in the scheme. Twenty-eight out of 32 respondents were undergraduates, compared to only 4 postgraduates. Regarding nationality, 25 of 34 respondents were from the UK, 7 international and $2 \mathrm{EU}$. This data cannot be used to conclude who is participating in the scheme, and is unlikely to be of use in knowing which student groups to target in the future.

The addition of the 'Stradents' pre-sessional sale showed how effective targeting certain groups of stu- dents properly can be. This sale was organised in two days and was advertise to pre-sessional students through the Stradents Facebook page, Facebook groups for pre-sessional students, and the University's 'me-chat' messenger groups, over 100 students attended.

\section{DISCUSSION}

The 2016/17 Shift Your Stuff campaign had mixed results. Flaws encountered previously in the scheme were avoided through refinements to the procedure and being better prepared for the sorting process. A SWOT analysis of the 2016/17s scheme was generated (Table 8). The requirements of the scheme were better communicated, but some restricted items were still donated; this was not too much of a problem as it was anticipated and places to send such items were organised. Other issues continued to occur despite changes being made to try and avoid them. Again, contact with charities was limited, and in turn response to follow up questionnaires was low. In future a better method of communication should be organised with charities early on in the process, such as getting responses whilst they collect donations.

Sticking to the time schedule of the protocol was challenging, with some team members not knowing when tasks needed to be completed by, or failing to meet the deadlines set out in the protocol. Other deadlines which were agreed during planning meetings were also not met, particularly the agreed upon deadlines for when the team should begin marketing the campaign; marketing was not launched until over a month after the target launch date. Agreements were also made to launch the drop-off points earlier in the term to allow longer for drop-offs, but due to delays with bags this target was not achieved. Informal discussions revealed that the snap general election which was called in the run up to Shift Your Stuff diverted a lot of the time and resources which would have been invested in promoting and marketing the scheme. This may have had an impact on how many students heard about the scheme and reduced potential participation, as well as impacting the timeline of events during planning.

Another observation is that some of the most successful reuse schemes at other HEls are at universities where

TABLE 7: Summary of the social benefits brought about by each charity that participated in the scheme, as reported through the charities by email or through websites.

\begin{tabular}{|c|c|}
\hline British Heart Foundation & $\begin{array}{l}\text { BHF use donations in a variety of ways including funding Nursing Care for those with heart problems, funding re- } \\
\text { search into the diagnosis, prevention and treatment of heart disease, social support for heart disease sufferers. They } \\
\text { also fund CPR training, distribute defibrillators, provide educational resources and keep BHF charity shops running } \\
\text { (BHF, 2016a). }\end{array}$ \\
\hline Southampton Refugee Action & $\begin{array}{l}\text { Refugee Action provides advice for refugees and asylum seekers, gives practical support to those resettling in the } \\
\text { UK and support organisations working with refugees. Donations went directly to be used by refugees and asylum } \\
\text { seekers re-settling in and around Southampton (Refugee Action, 2017) }\end{array}$ \\
\hline Two saints-Patrick House & $\begin{array}{l}\text { Two saints-Patrick house offer safe accommodation for the homeless, and support those with homes to help them } \\
\text { maintain their independence by offering free learning services and help with job hunting (Two Saints, 2016). }\end{array}$ \\
\hline St Francis Animal Welfare & Care for, rehabilitate and re-home numerous domestic animals (St Francis, 2017). \\
\hline Dogs Trust & Care for, rehabilitate and re-home dogs (Dogs Trust, 2017). \\
\hline Jamie's Computers & $\begin{array}{l}\text { A computer recycling social enterprise which aims to provide education and work experience through hands on } \\
\text { training for its service users. It is run by the society of St James who address poverty, sickness, hardship and distress } \\
\text { (Jamie's Computers, 2016). }\end{array}$ \\
\hline
\end{tabular}




\begin{tabular}{|c|c|}
\hline Strengths & Weaknesses \\
\hline Donations were of a higher quality than previous years- higher reuse rate. & Lack of volunteers \\
\hline $\begin{array}{l}\text { Most items were pre-sorted in categories, meaning minimal sorting time } \\
\text { was required. }\end{array}$ & $\begin{array}{l}\text { Despite charities agreeing collection times, some did not turn up at their } \\
\text { agreed time- causing issues for the sorting teams. }\end{array}$ \\
\hline Charities organised collection times and amounts in advance. & $\begin{array}{l}\text { Issues relating to kerbside donations being damaged by scavengers and } \\
\text { bad weather. }\end{array}$ \\
\hline $\begin{array}{l}\text { Charities collected soon after sorting meaning less storage space was } \\
\text { needed. }\end{array}$ & $\begin{array}{l}\text { Some donations were unsuitable for re-use- i.e. dirty clothes, broken items, } \\
\text { sharp knives and electricals. }\end{array}$ \\
\hline Photographic data allowed quick data collection. & Total weight of donations was lower than in previous years. \\
\hline $\begin{array}{l}\text { A sale was set up to provide pre-sessional students with kitchenware and } \\
\text { raise money for RAG charities. }\end{array}$ & $\begin{array}{l}\text { Marketing was launched later than planned, meaning fewer students may } \\
\text { have heard about the scheme than would have otherwise. }\end{array}$ \\
\hline $\begin{array}{l}\text { Data was collected for the KPIs, which allows comparison with the previous } \\
\text { year. }\end{array}$ & $\begin{array}{l}\text { Demographic stickers were filled in by very few students, meaning that the } \\
\text { data isn't useful for future years }\end{array}$ \\
\hline The scheme set a good example for sustainable waste management & Participation in the scheme was low, with only 548 bags donated. \\
\hline Students' unwanted items were diverted from disposal. & Low response from charities to the economic and social questionnaires. \\
\hline $\begin{array}{l}\text { The scheme was supported by SCC and BHF, as well as several other uni- } \\
\text { versities. }\end{array}$ & $\begin{array}{l}\text { Some bags contained items from a mixture of categories, meaning they } \\
\text { took time to re-sort. }\end{array}$ \\
\hline \multicolumn{2}{|l|}{ Scheme may have prevented litter on the streets. } \\
\hline Opportunity & Threats \\
\hline $\begin{array}{l}\text { Possibility for expansion/more support if partnerships are formed with } \\
\text { more charity groups within and outside of the University, and with other or- } \\
\text { ganisations such as Solent University. }\end{array}$ & $\begin{array}{l}\text { Lack of student involvement with SUSU may be leading to low interest/par- } \\
\text { ticipation. }\end{array}$ \\
\hline $\begin{array}{l}\text { Better support from the University could allow better recognition of the } \\
\text { scheme from students. }\end{array}$ & $\begin{array}{l}\text { Not including data from the halls collections may make the figures look low- } \\
\text { er than they are. }\end{array}$ \\
\hline \multicolumn{2}{|l|}{$\begin{array}{l}\text { Large potential for food collections if that aspect of the scheme is pushed } \\
\text { further. }\end{array}$} \\
\hline $\begin{array}{l}\text { Large potential for food collections if that aspect of the scheme is pushed } \\
\text { further. }\end{array}$ & \\
\hline
\end{tabular}

there is a strong relationship between the university/student's union and the student body. This close link may mean that students are more exposed, and pay more attention, to publicity for the scheme put out by the university. Students may be more likely to participate in the scheme if they have a good working relationship, and trust in, the organiser of the scheme.

The pre-assigned categories continued to minimise the amount of time required in the sorting process, with only a small amount of sorting/categorising required during the process. Additionally, the quality of donations was increased, resulting in a reuse rate of $92.4 \%$. Sorting was carried out consistently, with the same equipment being used. Additional volunteers were brought in during the second round of sorting to deal with the larger quantities, but the same people were leading the sorting process to eliminate inconsistencies. Detailed guidance was given on instruction sheets handed out with the donation bags; these detailed which items fell into each category. For the most part, these categories were stuck to and very few items needed to be re-bagged. Despite the guidance, some prohibited items were still donated: $9 \mathrm{~kg}$ of sharp knives were donated, along with various other unsafe, non-accepted items (Figure 4). The safest disposal route for these was to the police knife amnesty, a contingency which should be planned for in advance in future years.

The kerbside collection was well utilised on both collection days: on the first collection day $151 \mathrm{~kg}$ was dropped-off compared to $225 \mathrm{~kg}$ collected through kerb- side collection. During phase two $1094 \mathrm{~kg}$ was donated through campus drop-off points compared to $612 \mathrm{~kg}$ through kerbside collection. One problem which was relayed through the council's collection team was scavenging. To utilise the kerbside collection service students were advised to put their bags out on the morning of the collection day, evidently for some students this was not a suitable time and so they put their bags out earlier, some up to a week before the collection day. During the time that the bags were left on the streets some experienced damage through vandalism, bad weather and scavenging. Many bags were ripped open and contents strewn across pavements by people in search of useful or valuable items. The collection team estimated that around $50 \%$ of all bags left out for collection had been damaged or tampered with, meaning that they couldn't be collected for reuse. Street cleaning teams would then have to visit the student areas to clean up the resulting mess. So, in this situation, the scheme which has set out to reduce litter issues on the streets has inadvertently created mess on the streets; this was not the fault of the students. Discussions involved the consideration of working more closely with the council in future years to create 'safe' drop-off points where donations could not be tampered with. This action could dramatically increase the amount of successful donations made, and reduce costs involved in clearing the resultant mess, this should be followed up in future years to see if the city council would be willing to play a more active role in the scheme. 

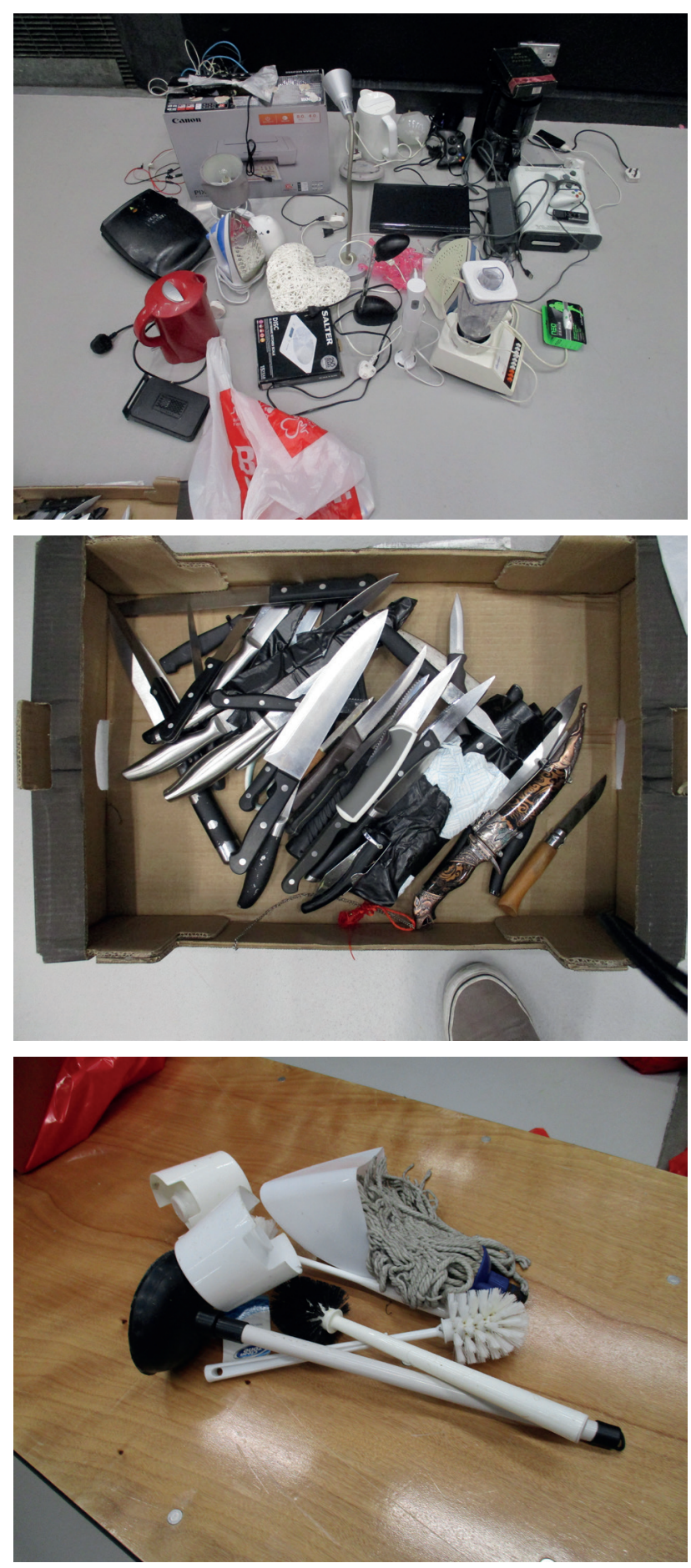

FIGURE 4: Prohibited items which were donated. electricals, knives, toilet brushes.

Volunteer recruitment continued to be a problem, with no-one signing up for the first session. For the second session, volunteers were recruited from the SUSU staff, meaning that there were fewer problems with people not turning up.

From analysis of similar schemes at universities across the country (Appendices 1,2), it can be seen that these types of scheme have the potential to be hugely successful. Warwick University collected over 82 tonnes of donations from a student population of 24,000 (Warwick University, 2015). The collaboration of various HEls and charities in Bristol produces outstanding results each year. The Bristol 'Big Give', a joint initiative between Bristol Waste Company, University of Bristol, Bristol SU, UWE, USESU, various student housing providers and the Charities BHF and Bristol HUB, brought in 96 tonnes of donations during 2017 (as of 24th June 2017). The Big Give has been running for 6 years, 3 of which has been in partnership with the BHF and is perhaps one of the best examples of a successful model for a HEl reuse scheme (Bristol, 2017).

The most successful HEls have committed time and resources to develop and improve their schemes over years, due to the need for understanding and recognition of the scheme through the student community. These schemes seem to take several years to become well-established; during this time it is important to commit resources to the expansion of the scheme. A possible key factor in the scheme success could be the faith that the students have in the organisation that is running it. The Southampton University Student's Union is known to have a poor reputation amongst Southampton students, many students feel that they are poorly represented by the Union (HEFCE, 2017), and therefore may have little interest in the activities and schemes that are run by SUSU, and be less inclined to participate.

A possible way to boost the power of the scheme and expand to other universities would be to make use of a consortium such as the Southern Coast Affinity Group (SCAG). By collaborating with other HEls and organisations such as WCAs and local authorities the scheme could have the potential to expand its coverage, participation and successthe more organisations are involved the more marketing and recognition the scheme will receive. A partnership such as this could boost Shift Your Stuff to a similar scale of projects such as the Bristol Big Give.

There are a number of options for the future of the scheme. The simplest option for SUSU is to carry on running the scheme. It is unlikely that this method will allow the scheme to grow (donations have decreased every year), but it will still allow the Union to exercise a sustainable waste management scheme and make charitable contributions, whilst contributing to litter management in Southampton. This method uses leaflets, posters and a small level of social media advertising to raise awareness of the scheme, but has limited reach to students, which may explain the limited participation.

Another option for SUSU to consider is increasing their effort in the scheme. By investing more effort into the marketing and advertising of the scheme, it could have a larger reach and therefore be more successful in terms of donations. This could be done by improving the student outreach of the scheme; due to restrictions the Union are limited on how much contact they can have with student groups, but with more involvement from the host university the scheme may be able to be advertised to more students who are not otherwise reached by SUSU's social media streams. Doorto-door contact could also be beneficial in increasing participation. In the 2014/15 Shift Your Stuff over 4 tonnes of donations were brought in, the main change to the scheme 
being the loss of door-to-door bag drop-offs. Students may be more likely to participate in a scheme if it requires minimal effort from them. This method should also incorporate targeting of international students- when leaving University, most international students will get rid of most of their household items (anything that isn't worth travelling thousands of miles with), meaning that they are a good source of reusable items.

It is clear that some of the more successful schemes are those which involve partnerships between various organisations. The University of Southampton could explore the possibility of partnering with other HEls in the area such as Solent University and the University of Winchester. If the opportunity arose it would also be beneficial to partner with a charity group such as Southampton RAG or Southampton HUB. By partnering with a charity group, Shift Your Stuff could be better supported in terms of resources for volunteers, have a wider reach for advertising through social media channels and have access to people who have good experience with such schemes who can advise in making it run more smoothly- all of which have been issues for Shift Your Stuff in the past.

Working more closely with Southampton City Council would be valuable for the scheme. This would be beneficial for both parties in that it could make the scheme more successful, reduce litter on the streets, and therefore reduce the costs and time involved with clearing it up. The council could aid the scheme by assisting with logistics and marketing, as well as possibly being able to help devise a way of making donations more secure on the streets. Collaboration between all possible parties could help the scheme meet its full potential. Involving organisation from across Southampton could make Shift Your Stuff a city-wide event rather than a scheme which is confined to student areas.

If SUSU feels that it cannot commit enough staffing and resources to expand the project to meet its full potential, it should be considered that the responsibility for running the charity collection could be handed over to the BHF. The BHF runs 'Pack for Good' for over 80 Universities and is hugely successful, raising over £1.5 million since 2011. The charity has dedicated teams to run the scheme in each region, meaning that they are experts at what they do and know exactly how to optimise the scheme to collect maximum donations. The BHF would take responsibility for all advertising, collections and sorting, meaning that SUSU would have minimal input of resources to the scheme. The only downfall to this scheme would be that all donations go to one charity, meaning that it cannot help local charities as it does currently.

\section{CONCLUSIONS}

The Shift Your Stuff scheme has successfully enabled reuse of household items that young people (in this case, students) would otherwise have thrown away, diverting waste from landfill and from the streets of a major urban centre (in this case, Southampton). The use of KPIs as a measure of success is providing a way to compare results year-on-year, and assess the impacts of the scheme. De- spite succeeding in its general purpose, Shift Your Stuff has the potential to become a much more successful scheme, in that it could bring in more donations and in turn have better environmental, social and economic benefits. In comparison to other schemes at UK HEls, Shift Your Stuff is bringing in a small amount of donations given the amount of students at the University of Southampton. From analysis of similar schemes, it is advised that the Students' Union looks to expand the scheme, either by collaborating with other organisations, or by passing on the responsibility of running the scheme to a charitable organisation that is set up for this purpose (e.g. the British Heart Foundation's Pack for Good campaign).

\section{REFERENCES}

Alexander, C. and Smaje, C. (2008). Evaluating third sector reuse organisations in the UK: Case-studies and analysis of furniture reuse schemes. Resources, Conservation and Recycling 52, 719-730.

British Heart Foundation (BHF) (2016a). About Us [Online]. Available: https://www.bhf.org.uk/about-us [Accessed 20/08/17].

BHF (2016b). Pack For Good [Online]. Available: https://www.bhf.org. uk/shop/pack-for-good [Accessed 28/02/17 2017].

Bianchi, C. and Birtwistle, G. (2010). Sell, give away, or donate: an exploratory study of fashion clothing disposal behaviour in two countries. The International Review of Retail, Distribution and Consumer Research, 20, 353-368.

Birtwistle, G. and Moore, C. M. (2007). Fashion clothing-where does it all end up? International Journal of Retail \& Distribution Management, 35, 210-216.

Love Where You Live Bristol (2017). Bristol Big Give [Online]. Available: http://lovewhereyoulivebristol.co.uk/bristol-big-give/ [Accessed 02/03/17 2017].

Bruce, M. and Daly, L. (2006). Buyer behaviour for fast fashion. Journal of Fashion Marketing and Management: An International Journal, 10, 329-344.

Cachon, G. P. and Swinney, R. (2011). The Value of Fast Fashion: Quick Response, Enhanced Design, and Strategic Consumer Behavior. Management Science, 57, 778-795.

Castellani, V., Sala, S. and Mirabella, N. (2015). Beyond the Throwaway Society: A Life Cycle-Based Assessment of the Environmental Benefit of Reuse. Integrated Environmental Assessment and Management, 11 (3), 373-382.

Del Borghi, A., Gallo, M. \& Del Borghi, M. (2009). A survey of life cycle approaches in waste management. International Journal of Life Cycle Assessment, 14, 597-610.

Dogs Trust (2017). About Us [Online]. Available: www.dogstrust.org. uk/about-us/ [Accessed 20/08/17].

Diop, S-A., \& Shaw, P. (2018). End of use textiles: gifting and giving in relation to societal and situational factors. Detritus, 1, 155-161.

Fortuna, L.M. and Diyamandoglu, V., (2016). A novel method for material characterisation of reusable products. Waste Management, 52, 14-24.

Gosling, C. (2016). Students hit back after being blamed for turning Plymouth streets into 'rubbish dump'. Plymouth Herald.

Higher Education Funding Ccouncil for Englan (HEFCE) (2017). National Student Survey 2017- results [Online]. Available: http://www. hefce.ac.uk/lt/nss/results/2017/ [Accessed 10/08/17].

Hislop, H. (2011). Reinventing the wheel: a circular economy for resource security, Green Alliance.

Horne, S. (2000). The charity shop: purpose and change. International Journal of Nonprofit and Voluntary Sector Marketing, 5, 113-124.

ICAEW (2017). Environmental Key Performance Indicators [Online]. Available: http://www.icaew.com/en/technical/business-performance-management-community/data-and-kpis/kpi-library/environmental-kpis [Accessed 21/03/2017 2017].

Jamie's Computers (2016). About Us [Online]. Available: http://jamies. org.uk/about-us/ [Accessed 20/08/17].

Joung, H. M. and Park-Poaps, H. (2013). Factors motivating and influencing clothing disposal behaviours. International Journal of Consumer Studies, 37, 105-111. 
Joy, A., Sherry, J. F., JR., Venkatesh, A., Wang, J. and Chan, R. (2012). Fast Fashion, Sustainability, and the Ethical Appeal of Luxury Brands. Fashion Theory-the Journal of Dress Body \& Culture, 16, 273-295.

Keep Britian Tidy, 2013. The Big Litter Inquiry: The public's voice on litter. Keep Britain Tidy.

Kozinets, R. V. and Handelman, J. M. (2004). Adversaries of consumption: Consumer movements, activism, and ideology. Journal of Consumer Research, 31, 691-704.

Morgan, L. R. and Birtwistle, G. (2009). An investigation of young fashion consumers' disposal habits. International Journal of Consumer Studies, 33, 190-198.

Patel, C. (2016). Using third dector reuse to reduce waste and create a sustainable legacy. University of Southampton, Unpublished data.

Bristol Post. (2016). Calls for action as Bristol student's rubbish left to fester. Bristol Post.

Refugee Action (2017). About Us [Online]. Available: http://www.refugee-action.org.uk/about/ [Accessed 20/08/17].

Resta B. and Dotti S. (2015). Environmental impact assessment methods for textiles and clothing. Handbook of Life Cycle Assessment (LCA) of Textiles and Clothing, pp. 149-191.

Two Saints (2016). Southampton, Eastleigh \& The New Forest [Online]. Available: http://www.twosaints.org.uk/southampton-eastleigh-the-new-forest/ [Accessed 20/08/17].

St Francis. (2017). About Us [Online]. Available: http://www.stfrancisanimalwelfare.co.uk/about-us.php [Accessed 20/08/17]
Sull, D. and Turnoconi, S. (2008). Fast fashion lessons fast fashion industry. Business Strategy Review, 19, 5-11.

Students and Staff of the Centre for Environmental Science (2017). Editorial: Millennials to the rescue? Waste Management, 62, 1-2.

Warwick Univeristy,. 2015. Charity 2015 [Online]. Available: http:// www2.warwick.ac.uk/services/accommodation/studentaccommodation/charity2015 [Accessed 28/02/17 2017].

Waddington, S. (2016). Students blamed for leaving Plymouth streets in 'disgusting' mess. Plymouth Herald.

Williams, I.D. and Taylor, C. (2004). Maximising household waste recycling at civic amenity sites in Lancashire, England. Waste Management, 24(9), 861-874.

Williams, I.D. and Cole, C. (2013). The impact of alternate weekly collections on waste arisings. Science of the Total Environment, 445446, 29-40.

Williams, I.D. and Shaw, P.J. (2017). Editorial: Reuse: Fashion or future? Waste Management, 59, 1-3.

Williams, I.D. and Shaw, P.J. (2018). Key Principles for Reuse. Proceedings of SUM 2018, 4th Symposium on Urban Mining and Circular Economy, 21-23 May, Bergamo, Italy.

Waste and Resources Action Programme (WRAP) (2016). KPIs [Online]. Available: http://www.wrap.org.uk/content/kpis-0 [Accessed 20/03/2017 2017]

Zhang, N.; Williams, I.D.; Kemp, S. and Smith, N.F. (2011). Greening Academia: Developing sustainable waste management at higher education institutions. Waste Management, 31(7), 1606-1616.

APPENDIX 1: Summary table of reuse schemes at UK higher education institutions.

\begin{tabular}{|c|c|}
\hline University scheme & Details \\
\hline Aberdeen, University of & $\begin{array}{l}\text { Student accommodation clearance scheme where local charities benefit from unwanted items. } \\
\text { Permanent Swap Shop for exchanging/reuse. }\end{array}$ \\
\hline Bangor University & $\begin{array}{l}\text { Collaboration between Love Your Clothes, Bangor University Sustainability Lab and Bangor students' Union. Challenged } \\
\text { residents to donate } 1 \text { tonne of unwanted clothing to the pop up 'swap shop' to be donated to Age Cymru, BHF and a local } \\
\text { charity. } \\
\text { Workshops also given on sewing, upcycling, and clothing care and repair. }\end{array}$ \\
\hline Bath, University of & $\begin{array}{l}\text { Bath University provide general guidance on their website with details on what and how to donate to permanent donation } \\
\text { bins. Donation bags are provided in student accommodation. }\end{array}$ \\
\hline Bristol 'Big Give' & $\begin{array}{l}\text { Joint initiative from Bristol City Council, Bristol Hub, University of Bristol, University of Bristol Students' Union (Bristol } \\
\text { SU), the University of the West of England, UWE Students' Union (UWESU) and the British Heart Foundation. } \\
\text { Items collected from student halls. } 21 \text { donation points are placed around student areas from late April until mid-July. } \\
\text { Aim of collecting } £ 125,000 \text { worth of donations. } \\
\text { Summer } 2016: 78 \text { tonnes ( } £ 135,000 \text { value) } \\
\text { Donations benefit charities other than BHF including Lifecycle, St Peter's Hospice and Children's Hospice South West as } \\
\text { well as other local charities. } \\
\text { Door knocked to speak to over } 1000 \text { students about responsible waste management and the charity banks. } \\
\text { The scheme has been described to have "[a] profound impact on unsightly waste and fly-tipping at the end of term" and } \\
\text { to "aid relationship building between neighbours in areas with a high student population." }\end{array}$ \\
\hline Durham 'Green Move Out' & $\begin{array}{l}\text { The scheme was launched in } 2005 \text { and has grown every year since. } \\
\text { Everyone in halls is provided with a bag and instructions ahead of move out period. Additional bags are provided at halls } \\
\text { receptions. } \\
\text { Guidance on how to donate: books, food, sharp/fragile items. } \\
\text { Private rented houses provided with bags and instructions ahead of move out period. Place outside for kerbside collec- } \\
\text { tion on pre-specified day. } \\
\text { Categories: clothing, shoes, bedding, electrical items, pots and pans, crockery. } \\
\text { Local charities including County Durham Furniture Help scheme, Durham Palestine Educational Trust, East Durham Trust, } \\
\text { A Way Out. }\end{array}$ \\
\hline $\begin{array}{l}\text { Imperial- end of term reuse } \\
\text { scheme }\end{array}$ & $\begin{array}{l}\text { Food collection boxes placed in halls kitchens during move out period, (2014- } £ 8000 \text { worth of food donations, around } 2 \\
\text { tonnes). } \\
\text { British heart foundation runs the main collection scheme with collection bin placed around halls. BHF bags delivered to } \\
\text { all halls rooms. Collection point in common rooms/receptions. }\end{array}$ \\
\hline LSE 'Relove' & $\begin{array}{l}\text { Reuse program that runs at the end of academic year. Donations go to the BHF. } \\
\text { Some selected items are stored over summer and offered to students in exchange for a donation at the start of the year } \\
\text { (proceeds go to their Students' Union sustainability projects). }\end{array}$ \\
\hline Sheffield 'donate don't waste' & $\begin{array}{l}\text { Collaboration between Sheffield University and Sheffield Hallam University. } \\
\text { Donation bags and donation points are provided in halls. } \\
\text { Donation bags are also available from the SU for students living in private accommodation, donation points located in } \\
\text { the SU. } \\
\text { Scheme also incorporates a summer food drive, collection points at halls and SU. In } 2016 \text { this collected over } 3000 \text { items. } \\
\text { The council provide } 2 \text { red sacks per person to be collected in addition to the regular household waste collection during } \\
\text { move out period for anything that cannot be re-used/recycled. This is to help with street litter issues; this waste is sent } \\
\text { for incineration. }\end{array}$ \\
\hline
\end{tabular}




\begin{tabular}{|c|c|}
\hline University scheme & Details \\
\hline Solent 'Eco Ernie' & $\begin{array}{l}\text { This scheme was launched in } 2008 \text { and involves door to door collections around student areas at the end of the summer } \\
\text { term using a milk float. } \\
\text { Bags are distributed to students in private accommodation towards the end of the academic year. The scheme held } 6 \\
\text { collection days for private housing, and } 3 \text { for student halls. } \\
\text { The best items are resold at a 'church bazaar' and the rest is recycled or scrapped. } \\
\text { Piggybacked by the 'Give a Bra' which provided bags specifically for bras to be sent to west Africa. } \\
\text { Unlike many other collections, duvets were accepted to become bedding for horses. } \\
\text { Textiles donated to the Hampshire and loW Air Ambulance. }\end{array}$ \\
\hline St Andrews 'St AndRe-Use' & $\begin{array}{l}\text { Throughout the year 'St AndRe-use' open drop off points around the campus. } \\
\text { Items collected are redistributed to students for free at 'The Big Giveaway' during Freshers' week and 'The Slightly Smaller } \\
\text { Giveaway' at the start of Semester } 2 \text {. } \\
\text { Two major collection drives occur at the end of each term in Halls of Residences and one or two other University locations. }\end{array}$ \\
\hline Warwick, University of & $\begin{array}{l}\text { As well as participating in BHF Pack for Good, Warwick run a separate food collection at the end of the academic year, in } \\
2015 \text { this brought in } 16.7 \text { tonnes of food (RAWKUS project). } \\
\text { Curtains and curtain poles from refurbished halls donated to BHF and } 152 \text { chairs to the Coventry city mission. } \\
5,300 \text { used duvets collected from campus rooms and donated to charities which help homeless women and refugees. }\end{array}$ \\
\hline
\end{tabular}

APPENDIX 2: Summary table of some successful 'Pack for good' schemes at various UK Universities.

\begin{tabular}{|c|c|}
\hline University & Details \\
\hline $\begin{array}{l}\text { Birmingham University 'Junk- } \\
\text { busters' }\end{array}$ & $\begin{array}{l}\text { The pilot scheme for the "Pack for good" campaign. } \\
\text { Aim to reduce waste left on the streets and raise funds for BHF. } \\
\text { Amount raised to date: } £ 86,000 \\
2013 / 13 \text { nearly } 1800 \text { bags were collected worth over } £ 14,000 \\
\text { Collect bags on an eco-friendly milk float. } \\
11 \text { collection days between May and early July. }\end{array}$ \\
\hline Cambridge, University of & $\begin{array}{l}\text { 2013: } 1998 \text { bags collected } \\
\text { 2014: } 3043 \text { bags collected } \\
\text { 2015: } 6644 \text { bags, equivalent to } 53.1 \text { tonnes. Collected between } 1^{\text {st }} \text { April- } 31^{\text {st }} \text { September. Value to BHF: } £ 93,016 \text {. Net ben- } \\
\text { efit by } \mathrm{CO}_{2} \text { emissions equivalent compared to landfill: } 54,040 \mathrm{~kg}\end{array}$ \\
\hline Chester, University of & $\begin{array}{l}\text { Working together since } 2012 \\
2015 \text { campaign: collaboration between Uni of Chester and 'Fresh Student Living' (private accommodation). April-Sep- } \\
\text { tember campaign period. } \\
613 \text { bags donated, equates to } 4.9 \text { tonnes ( } £ 8582 \text { value). Net benefit by } \mathrm{CO}_{2} \text { emissions equivalent compared to landfill: } \\
4987 \mathrm{~kg} \text {. }\end{array}$ \\
\hline Coventry University & 2015: Estimate of $£ 30,000$ worth of donations. From 2,265 bags. \\
\hline Derby, University of & 2015: 1041 bags collected, stock value $£ 14,500$. April-July. \\
\hline Edinburgh, University of & $\begin{array}{l}\text { Student led approach } \\
\text { Partnership with BHF, SHRUB (student led swap and reuse hub), TIC international. Identify varieties of waste and which } \\
\text { are valuable to each partner. } \\
\text { Good communication: posters, leaflets and social media. Recruiting volunteers: student to student communications work best. } \\
\text { Mailing list of student interested in sustainability- incentive of volunteers getting 'first dibs' on the donated items if they wish. } \\
\text { Giveaway of essential Uni items during move in week- eg pots and pans. }\end{array}$ \\
\hline Hull, University of & $\begin{array}{l}\text { 2013: } 522 \text { bags ( } 3.1 \text { tonnes) donated in total. Most donations early-mid June. Used a bag value of } £ 20 \text { - estimates } £ 10,440 \\
\text { value. } 31,874 \text { net benefit }\left(\mathrm{kg} \mathrm{CO}_{2} \text { equivalent compared to landfill. }\right. \\
\text { Press released prior to collections in the hull daily mail with donation guidance. } \\
\text { Local BHF gave a } 15 \% \text { discount for students wishing to purchase furniture/electrical to promote re-use. }\end{array}$ \\
\hline Leicester, University of & $\begin{array}{l}\text { 2014/15 academic year: } 674 \text { bags of old clothing and utensils from the ten donation bins placed across the accommo- } \\
\text { dation sites. }\end{array}$ \\
\hline Loughborough University & $\begin{array}{l}\text { 2014: permanent donation points, full marketing campaign } 1842 \text { bags donated. } \\
\text { 2015: Reps collected from halls, as well as donation points. } 2,467 \text { bags collected ( } £ 34,538 \text { value) } \\
\text { 2016: permanent donation banks, rep collections from halls, and pop up donation boxes during summer clear out. } 2,838 \\
\text { bags donated ( } £ 39,732 \text { value). }\end{array}$ \\
\hline Newcastle University & $\begin{array}{l}\text { Newcastle Uni, NUSU, Northumbria Uni, and Newcastle city council partnership with BHF. } \\
2016 \text { campaign: } 3,776 \text { bags donated ( } £ 87,220 \text { value). Been running since } 2012 \text {. }\end{array}$ \\
\hline Nottingham, University of & Donation bins (at points between accommodation and uni), food drop off points, and 'horse and dray' doorstep collection. \\
\hline Oxford, University of & $\begin{array}{l}2015: 56,336 \mathrm{~kg} \text { of donations ( } £ 99,288 \text { value). } \\
\text { Partnership between the City Council, Oxford Brookes and Oxford University Colleges. } \\
\text { Red bins placed around the city. Regular collections from some accommodation services throughout summer term. } \\
\text { Promoted through OUSU at the SU, on social media. }\end{array}$ \\
\hline Warwick, University of & $\begin{array}{l}\text { Top university collector three years running. } 15 \text { permanent collection banks, } 22 \text { pop up banks. } \\
2015 / 16 \text { academic year: } 82.9 \text { tonnes collected ( } £ 116,536 \text { value). }\end{array}$ \\
\hline York, University of & $\begin{array}{l}\text { Council makes extra collections of general waste during moving out period. Students and locals encouraged to donate } \\
\text { suitable items to clothing banks and drop off points at round uni. Info leaflets and maps of drop off points distributed prior } \\
\text { to the event. } 2014: 15.6 \text { tonnes of donations, } 1899 \text { bags ( } £ 38,000 \text { value). } \\
\text { Council reminding students how to dispose of waste responsibly ahead of and during move out period, and through } \\
\text { university social media. }\end{array}$ \\
\hline
\end{tabular}


APPENDIX 3: Email sent to students during volunteer recruitment drive.

Dear Students,

We are now recruiting volunteers to help us sort what we collect for Shift Your Stuff 2017. Last year we were able to sort over four tons of waste and this year we aim to recycle double that amount!

We are looking for student volunteers who available are anytime on June either 13th, 14th, 30th or July 1 st to join us and help with the sorting of tons of stuff. Volunteers will receive free pizza.

You can sign up directly with this link and or through our Facebook event. Full details of Shift Your Stuff can be found at www. unionsouthampton.org/shiftyourstuff.

\section{Don't rely on others to make the world cleaner.}

Join our Shift your Stuff project and help us clean the planet.

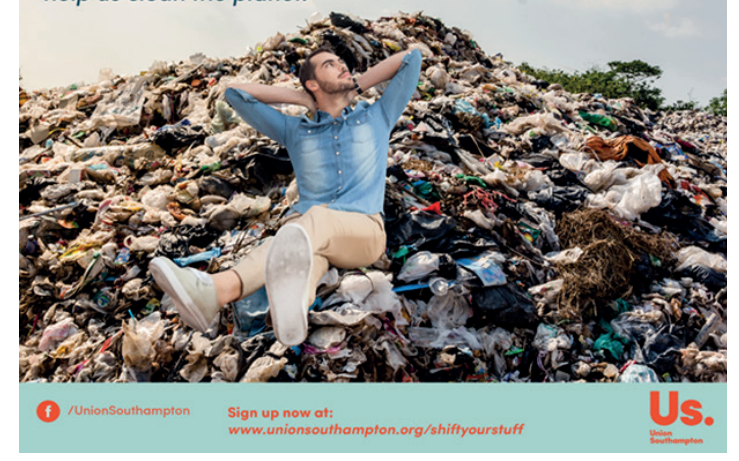

